\title{
Impact of Coal Mining in Forest Area to Carbon Emission in Kutai Kartanegara, East Kalimantan
}

Retna Kartikasari ${ }^{\mathrm{a}}$, Arief Rachmansyah ${ }^{\mathrm{b}}$ and Amin Setyo Leksono ${ }^{\mathrm{c}}$

a Master Programme of Natural Resource Management and Development, Postgraduate University of Brawijaya, 169th MT. Haryono Street, Malang, 65145, Indonesia, [+62] 8151477 5957, retna4k@gmail.com

b Department of Civil Engineering, Faculty of Engineering, University of Brawijaya, University of Brawijaya Complex, 167th M.T. Haryono Street, Malang 65145

c Department of Biology, Faculty of Mathematics and Natural Sciences, University of Brawijaya, Biology Building, Veteran Street, Malang 65113

\section{Article Info:}

Received: 14 - 08 - 2018

Accepted: $25-07-2019$

Keywords:

Coal mining, Forest Area, Landcover change, Carbon emission

Corresponding Author: Retna Kartikasari

Master Programme of Natural

Resource Management and

Development, Postgraduate

University of Brawijaya, 169th

MT. Haryono Street, Malang

Tel. +62-81514775957

Email: retna4k@gmail.com

\begin{abstract}
Coal mining is an activity that contribute to greenhouse gas emissions, both from methane gas release of coal trap and the loss of land cover plants. This study was conducted to estimate carbon emissions in coal mining areas inside forest areas by analyzing changes in landcover. The area of this study is Kutai Kartanegara Regency, East Kalimantan, where coal mining activities are quite massive. To obtain the extent of changes in land cover and the amount of carbon emissions in the area, analysis of Landsat 5 TM and Landsat 7 ETM+ imagery in 2010 and also the 2016 Landsat 8 OLI / TIRS imagery was used. The results showed that in the area of study there was a change in landcover of 12,663.28 Ha in the forest areas used for coal mining activities. Carbon emissions generated from this activity amounted to 0.60 Mton $\mathrm{CO}_{2}-\mathrm{Eq}$.
\end{abstract}

How to cite (CSE Style $8^{\text {th }}$ Edition):

Kartikasari R, Rachmansyah A, Leksono AS. 2019. Impact of coal mining in forest area to carbon emission in Kutai Kartanegara, East Kalimantan. JPSL 9(4): 1066-1074. http://dx.doi.org/10.29244/jps1.9.4.1066-1074.

\section{INTRODUCTION}

During the past 25 years, around $82 \%$ of the world's primary energy needs is coming from fossil energy, including coal (National Energy Council, 2014). Then, over the past 10 years, coal needs in Indonesia have risen sharply along with the addition of coal-fired steam power plants. This was also followed by the expansion of coal mining, especially in the Kaliman-tan region. Coal mining is one of the activities which drive economic growth in Indonesia and become a lever of local economic activities.

In Indonesia, forestry activities are still seen as a supporting sector to national and local economies, while its benefit on providing ecosystem protection, especially the provision of water and oxygen. Handoyo and Cicilia (2014), said that about USD 8.9 million total of forest product were exported from Indonesia to many countries, based on Ministry of Trading and Industry Therefore, those both sectors have prominent influence towards the economic growth and must be able to go concomitant. 
However, in fact a lot of coal mining activities take place in forest areas. Coal mining activities in East Kalimantan are partly located in forest areas. Su-hanto (2012) stated that $10 \%$ of the coal mines in are located in forest area.

Coal mining is an open-pit mining and consequent-ly, turns vegetated land into non-vegetated one. Coal mining consession in the forest area, then called forest use consession, causes carbon emission from the LULUCF (Land Use, Land Use Change and Forestry) sector. Sonya (2012) mentioned that LULUCF were responsible for 55 to $79 \%$ of the green house emission.

Carbon emission which caused by LULUCF need land cover change monitoring from two different time using remote sensing satellite. Olofssonet al. (2010); Ferreiraet al. (2011); Goetz and Dubayah (2011); Margono et al. (2012); and Sonter et al. (2013) con-ducted previous studies that observed forest resources monitoring using satellite imaging for analyzing the change of landcover in forest area. Furthermore, Munawar et al. (2015) explained satellite observation can be used for identifying deforestation and forest degradation and increasing carbon emission.

In study Abood et al. (2015), had revealed that $44.7 \%$ ( \pm 6.6 million hectares) of forest loss in Indonesia between 2000 and 2010, resulting in 4,577 to 8,662 million tons of CO2 in the concession areas. Therefore, we researched further studies on how much carbon emission from land cover changes in conces-sion area, which is forest areas used concession for coal mining activity. The objective of the study is to estimate carbon emission that caused by landcover change inside forest areas in in Kutai Kartanegara, East Kalimantan due to coal mining activity.

\section{METHOD}

\section{Area of Study}

The area of study is Kutai Kartanegara Regency, East Kalimantan Province. Kutai Kartanegara is located in $115^{\circ} 26^{\prime} 28^{\prime \prime}$ - $117^{\circ} 36^{\prime} 43^{\prime \prime}$ longitude and $1^{\circ} 28^{\prime} 21^{\prime \prime}$ - $1^{\circ} 08^{\prime} 06^{\prime \prime}$ latitude which has total area about 27263.10 $\mathrm{km} 2$. Its topography is bumpy to hilly with steep slope in which height is between 500-2,000 meters above sea level. It has humid tropical forest climate and different climate between hot and rainy season is subtle. Rainfall is between 2000 and $4000 \mathrm{mmy}-1$ and average temperature is $26^{\circ} \mathrm{C}$.

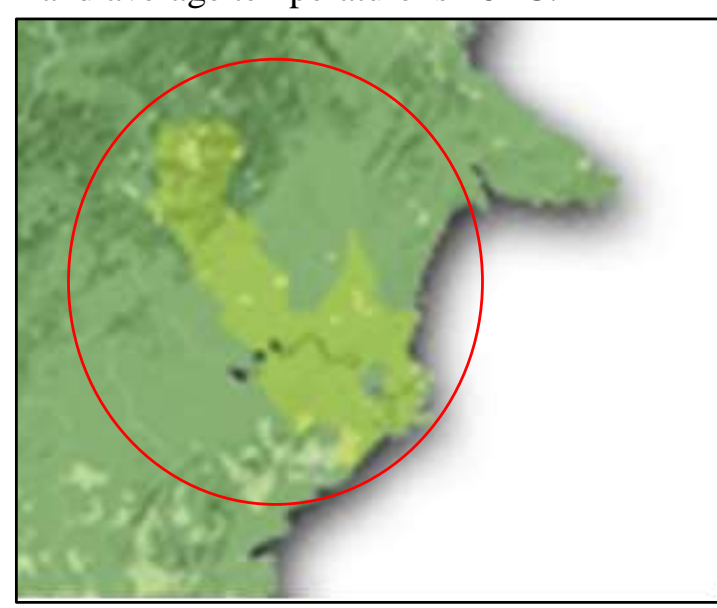

Figure 1 Area of study Regency.

(Source: http://kabupaten.kutaikartanegara.com)

Kutai Kartanegara is famous for their forest and energy resources, such as coal, oil and gas. Their forest commodity consists of wood commodities like Jabon (Neolamarckia cadamba), Kaliandra (Calliandra sp.)," and Sengon (Albizia chinensis), and non-wood commodities, which are rattan (Calamus sp.), "gaharu", aromatic products, honey, "matoa", fruit, and "jelutung", resin . Mining has a vital role towards Kutai 
Kartanegara economics. Both oil and gas as well as non-oil and gas resources are their primary export commodities. The total coal production in 2015 was 55844597.90 tons (from 73 coal mines).

In 2006, Kutai Kartanegara was dominated by forest consisting of shrubs, dense forest, swamp forest and forest used for industrial plantation; the total forest area in 2006 was $1858237 \mathrm{Ha}(68.16 \%$ of the total size of the municipality). $160369 \mathrm{Ha}$ are used for residential area; $53437 \mathrm{Ha}$ is used for ricefield; $183807 \mathrm{Ha}$ is for dry farm/moor; $70523 \mathrm{Ha}$ is for lake, swamp, fish farm and rivers, and the remaining $433346 \mathrm{Ha}$ consists of shrubs, reeds, shifting cultivation and excavation.

\section{Time of Study}

This study was held from February 2017 to February 2018. A year of study used to collecting and analyzing data. Most of time was used for interpreting Landsat Imagery.

\section{Materials}

All the data is secondary which obtained from many sources, such as literatures, internet, free satellite images, and thematic map. Satellite images used in this study are Landsat 5 TM, Landsat 7 ETM+ and Landsat 8 OLI/TIRS. Data on the 2010 landcover were obtained from the Landsat 5 TM and Landsat 7 ETM+ image interpretation, while the Landsat 8 OLI/TIRS images were used for the 2016 landcover identification (Table 1). These data is downloaded from https://earthexplorer.usgs.gov/.

This research also used SNI 7645: 2010 on the Landcover Classification and the 2015 Regulation of the Director General of Forestry Planology and Environmental on Guidelines for Forest Resources Monitoring for key of interpretation. Then, for reference of ground control point is using image of google earth. To narrow the area study that focused on forest use concession, digital map of forest use concession distribution of Kutai Kartanegara is being used. The source of this data is Directorate General of Forestry Planology and Environmental.

Table 1 Landsat Imagery used in the Study.

\begin{tabular}{cccl}
\hline No & Type of Image & Path/Row & \multicolumn{1}{c}{ Recording Time } \\
\hline 1 & & $116 / 061$ & May 19, 2010 \\
2 & \multirow{2}{*}{ Landsat 5 TM } & $116 / 060$ & $\begin{array}{l}\text { January 27, 2010 } \\
\text { May 3, 2010 }\end{array}$ \\
3 & & $117 / 060$ & December 30, 2010 \\
4 & & \multirow{2}{*}{$117 / 060$} & February 11, 2010 \\
\hline 5 & \multirow{2}{*}{ Landsat 7 ETM+ } & December 12, 2010 \\
6 & & $116 / 061$ & February 13, 2016 \\
\hline 7 & & August 7, 2016 \\
8 & & $116 / 060$ & January 28, 2016 \\
9 & \multirow{2}{*}{ Landsat 8 OLI/TIRS } & & February 20, 2016 \\
10 & & $117 / 060$ & March 7, 2016 \\
11 & & & April 8, 2016 \\
12 & & & \\
\hline
\end{tabular}

Source: USGS earth explorer, 2016

\section{Analysis Methods}

\section{Pre-image Processing}

Geometric correction was conducted on the Landsat 5 TM taken on May 19, 2010 using the Landsat 8 OLI/TIRS taken on August 7, 2016 as the reference. Pre-image processing was also conducted on the Landsat 7 ETM+ image because SLC off caused stripping on the image. This process called "gapfill" which required 1068 
one or more image scenes on the same path/row taken in different time. An image scene was used as basic image and another one was used as filling image. low Cloud closure level became the basis for basic image and filling image selection. The basic image was selected from scene of which cloud closure image was low on certain interpreted areas.

After gapfill has been completed, the landsat images were cut into several smaller pieces based on the concession areas and interpreted using 543 band combination band for Landsat 5 TM and Landsat 7 ETM + and 654 band combination for Landsat 8 OLI / TIRS. These combinations were selected based on the SNI 7645: 2010 on the Landcover Classification and the 2015 Regulation of the Director General of Forestry Planology and Environmental on Guidelines for Forest Resources Monitoring. The band combinations display a clear contrast between vegetated and non vegetated land.

\section{Image classification}

Based on the composite image, supervised classification was conducted using the maximum likelihood approach. The training area was determined based on the landcover maps and control points from the Google Earth image (map to map reference). There 488 reference points collected from Google Earth for 2010 and 488 reference points for 2016; the number was varied each scene. The reference points were the reference for creating a sample for the supervised classification.

\section{Landcover Change Analysis}

Post-classification comparison change detection, of which basis was classified raster data vectorization, was the method used to identify landcover change. Remote sensing technique can detect changes in the Earth's surface. While detecting, multitemporal data application for quantitative analysis should be implemented in order to analyze these changes from time to time.

\section{Carbon Emissions Estimation}

Different amount of carbon stock, from one landcover to another, was the type of information used to identify estimated amount of carbon emission (IPCC, 2006). Type of carbon emission analyzed in this study was carbon emission equivalent (CO2-eq), with conversion factor of 44/12 or 3.67 times carbon reserve (C ton/hectare). Its unit of measurement was Mton $\mathrm{CO} 2$-eq. Equation 1 is used to calculate the carbon stock difference.

$$
\Delta \mathrm{C}=\left(\mathrm{C}_{1}-\mathrm{C}_{0}\right)
$$

$\Delta \mathrm{C}$ is carbon stock difference (C Ton/Hectare); $\mathrm{C}_{0}$ is carbon stock on preliminary observation (C Ton); and $\mathrm{C}_{1}$ is carbon stock on final observation ( $\mathrm{C}$ Ton). Carbon Emission/Absorption is determined by Equation 2 .

$$
\mathrm{E} / \mathrm{A}=\Delta \mathrm{C} \times \mathrm{L}_{\mathrm{LCF}} \times 3.67
$$

$\mathrm{E} / \mathrm{A}$ is carbon emission/absorption (MTon $\mathrm{CO} 2$-eq); $\Delta \mathrm{C}$ is carbon stock difference in different landcover (C Ton/Hectare); $\mathrm{L}_{\mathrm{LCF}}$ is size of landcover change (Hectare). Thus, Carbon Emission/Absorption is calculated by Equation 3 .

$$
\text { Nett Emission = Emission }- \text { Absorption }
$$

Nett Emission referred to calculation between emission and its absorption in all landcover types. Emission took place carbon stock changed from high to low (+) while absorption took place when carbon reserve changed from high to low (-). 


\section{RESULTS AND DISCUSSION}

\section{Landcover Change in the Forest Use for Coal Mining Concession Areas}

Based on the 2010 and 2016 Landsat time series data, there was change in landcover pattern in the forested area and non-forested area (Table 2). There were 13 different types of landcover, which are: 1) secondary dry land forest, 2) forest plantation, 3) shrubs, 4) shrubs and swamp, 5) crop estate, 6) dry land farming, 7) dry land farming mixed shrubs, 8) rice field, 9) open area, 10) mining, 11) residential area, 12) water, and 13) swamp.

Table 2 Total Landcover Area for Forest Use for Coal Mining Concession Areas.

\begin{tabular}{|c|c|c|c|c|}
\hline \multirow{2}{*}{ No } & \multirow{2}{*}{ Landcover Type } & \multicolumn{2}{|c|}{ Size (Hectare) } & \multirow{2}{*}{$\begin{array}{c}\text { Change in Size } \\
\text { (Hectare) }\end{array}$} \\
\hline & & 2010 & 2016 & \\
\hline 1 & Secondary Dry Land Forest & 52280 & 517.57 & 23.51 \\
\hline 2 & Forest Plantation & 7112.78 & 5551.18 & 2535.22 \\
\hline 3 & Shrubsland & 31741.82 & 28416.03 & 6051.93 \\
\hline 4 & Shrubsland of Swamp & 205.46 & 208.10 & 40.35 \\
\hline 5 & Crop Estate & 20.87 & 45.65 & 6.69 \\
\hline 6 & Dry Land Farming & 22.31 & 23.91 & 4.09 \\
\hline 7 & Dry Land Farming mixed Shrubs & 283.22 & 739.77 & 71.02 \\
\hline 8 & Rice Field & 321.11 & 63.82 & 283.35 \\
\hline 9 & Open Area & 3252.95 & 6069.87 & 1603.24 \\
\hline 10 & Mining & 3906.26 & 5262.91 & 1735.03 \\
\hline 11 & Residential Area & 8.27 & 22.70 & \\
\hline 12 & Water & 639.53 & 1115.92 & 308.86 \\
\hline \multirow[t]{2}{*}{13} & Swamp & 0.36 & 0.36 & \\
\hline & Total & 48037.79 & 48037.79 & 12663.28 \\
\hline
\end{tabular}

Source: Data processing

There was 5.23 Ha decrease in the secondary dry land forest and $1561.60 \mathrm{Ha}$ in the forest plantation. Size of the shrubs and rice field also declined in 2016. 3210.42 ha of shrubs turned into open areas and 1801.20 ha of shrubs turned into mining areas. The remaining became shrubs and swamps, crop estate, dry-land farming, dry-land farming and shrubs, residential areas and water. $45.64 \%$ of the rice field turned into shrubs and $26.50 \%$ into mining areas. Besides that, the rice field also turned into dry-land farming and shrubs, open area and water.

Size of the mines increased from 3906.26 into 5262.91 ha or $2.82 \%$ in 2016. In the same year, approximately $12.64 \%$ of the open area became coal mining. There was $50 \%$ increase of water in the concession land from 639.53 Ha in 2010 into $1115.92 \mathrm{Ha}$ in 2016.

Sihombing (2013) argued that change in land clearing would result in degrading quality of land in the concession area. The number of non-vegetated area that turned into coal mines was far more than the vegetated area. It showed that forest destruction affect the quality of land in a significant number.

A lot of vegetated land in the concession area turned into coal mines. Instead of being used for coal excavation, the vegetated area supply soil for the coal mines. Excavation also floods the forest turning it into body of water (Yadav and Borana 2017). Samanta (2015) highlighted major change in land clearing. As the result of land clearing, conversion of land into coal mines, $53.95 \mathrm{~km}^{2}$ of primary forest and $117.37 \mathrm{~km}^{2}$ of secondary one were destroyed. 


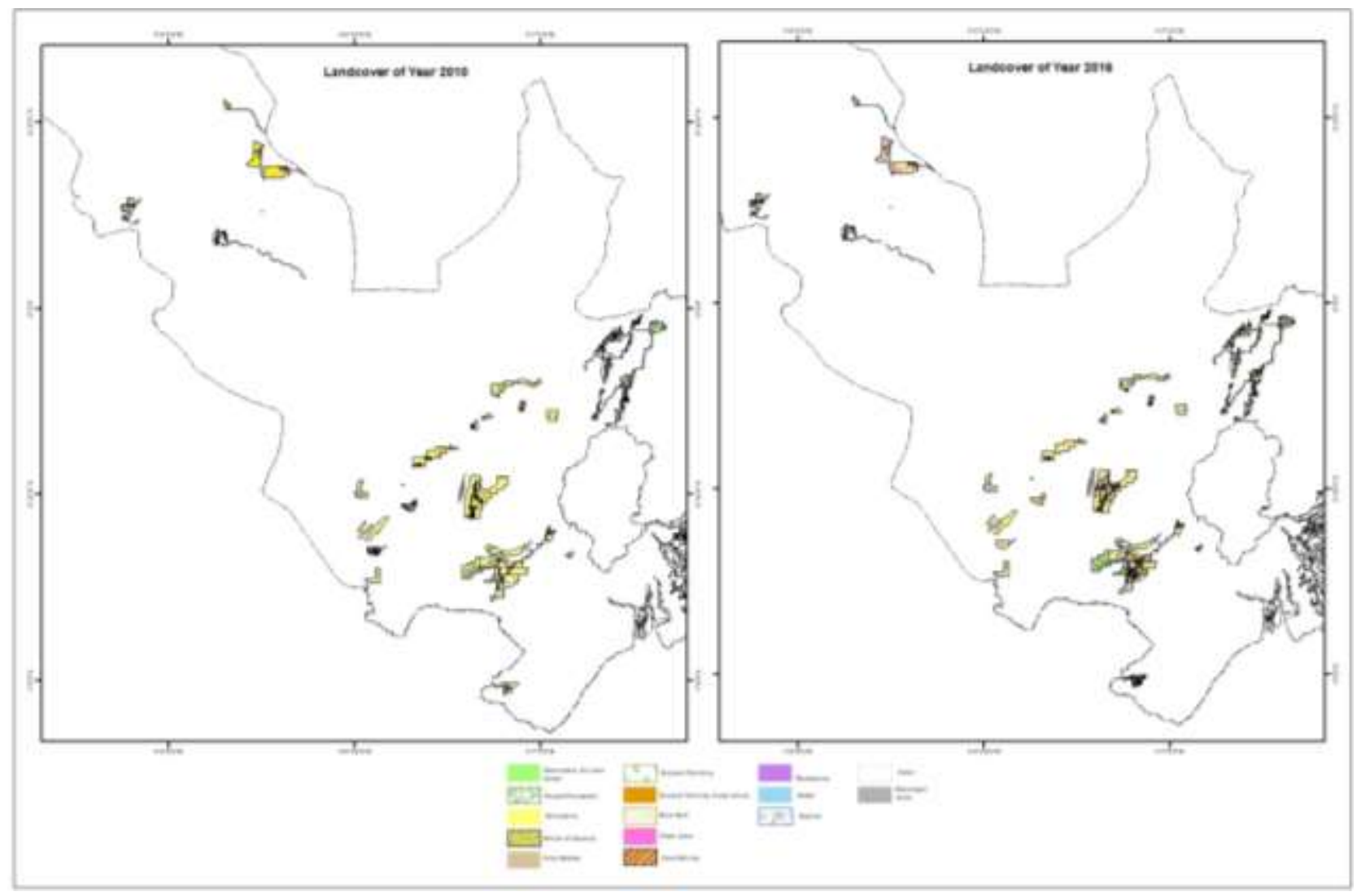

Figure 2 Landcover in the Concession of Coal Mining Area in the Forests of Kutai Kartanegara between 2010 and 2016.

\section{Carbon Emission in the Forest Use for Coal Mining Concession Areas}

Coal mine applies open-pit system and as the result, requires land clearing for its production activities. Land clearing for coal mine turns vegetated area into non-vegetated one or even vegetated area into water. Guan et al. (2017), finding that coal mining in the Xilingol meadows showed seven classes of land use, i.e.: open stope, stripping area, waste disposal area, mining industry area, agricultural land, urban area and grassland. The presence of surface coal mining disrupts the pasture ecosystems so the area fell by 8661.15 $\mathrm{Hm} 2$ in 2005-2015. The mining operation area and its infrastructure increase.

It can affect carbon stock of the area above. Turning vegetated area into mine or no-vegetated area other than mine will decrease amount of carbon reserve. This will result in carbon emission. Agus et al. (2013) stated that mine does not have any carbon stock (zero carbon stock). Furthermore, Huang et al. (2014) stated that the vegetation located in the area near Xinzhouyao coal mine was disturbed, both its growth rate and its ability to absorb carbon, so the carbon stock in the area would decrease and its carbon emissions would increase.

Table 3 shows that, emission meant decreasing amount of carbon stock while absorption meant the carbon stock was increasing. The shrubs was the type of land in the concession area producing the highest carbon emission and the open area had the highest carbon absorption. $\mathrm{CO} 2$ emission will be increased because no longer vegetation which absorb it. These vegetations role as Carbon-sink.

The shrubs produced carbon emission when they became open area or mines. According to Wright and Wimberly (2013) and Lark et al. (2015) in Ahlehring (2016), it is important to protect grasslands/shrublands from conversion because of its carbon stock has a high risk of loss to the atmosphere. Gunawan et al. (2017) stated that the carbon reserve was declining from 369910 tons in 2010 to 310640 tons in 2015 due to land conversion. The forests and shrubs turned into agricultural and residential areas. 
Meanwhile, most of the land areas turned into shrubs and vegetated area and therefore, had high carbon absorption In Adhikari and White (2016), shrubland can increase carbon sequestration. In this context, mining area had contribution towards carbon absorption because changing the mines into vegetated areas (forest plantation, shrubland, dry-land farming mixed shrubs, rice field and open area) increased the amount of carbon reserve.

Table 3 Carbon Absorption and Emission (C) of each Landcover.

\begin{tabular}{rlrrr}
\hline No & \multicolumn{1}{c}{ Land Clearing } & Absorption & Emission & \multicolumn{1}{c}{$\begin{array}{c}\text { Net emisi } \\
\text { (C ton) }\end{array}$} \\
\hline \hline 1 & Secondary Dry Land Forest & - & 3869.73 & 3869.73 \\
2 & Forest Plantation & $(445.65)$ & 121272.70 & 120827.05 \\
3 & Shrubsland & $(5251.90)$ & 152402.76 & 147150.86 \\
4 & Shrubsland of Swamp & $(5.94)$ & 625.75 & 619.81 \\
5 & Crop Estate & - & 322.51 & 322.51 \\
6 & Dry Land Farming & $(16.20)$ & 32.37 & 16.17 \\
7 & Dry Land Farming mixed Shrubs & $(161.88)$ & 1572.93 & 1411.04 \\
8 & Rice Field & $(4224.66)$ & 173.09 & $(4051.57)$ \\
9 & Open Area & $(51368.05)$ & 605.61 & $(50762.45)$ \\
10 & Mining & $(48019.74)$ & - & $(48019.74)$ \\
11 & Residential Area & - & - & - \\
12 & Water & $(7195.58)$ & - & $(7195.58)$ \\
13 & Swamp & - & - & - \\
\hline \hline & & $(\mathbf{1 1 6} 689.60)$ & $\mathbf{2 8 0 ~ 8 7 7 . 4 3}$ & $\mathbf{1 6 4} \mathbf{1 8 7 . 8 3}$ \\
\hline \hline Sour
\end{tabular}

Source: Data processing

Reclamation and revegetation turned the mines into forest resulting lower carbon absorption from the shrubs. In their study, Lutfi and Antono (2011) described that PT Gunung Bayan Pratama Coal produced 22 351 Tons/Hectare carbon stock in the reclamation area and 29675 Tons/Hectare in the Base Line/secondary forest. Furthermore, Amichev et al. (2008) revealed that the rate of carbon sequestration in a mining area may be higher between before and after reclamation, depending on the quality of plant species used for post-mining planting in carbon sequestration.

In coal mines located in forest area, carbon emission is identifed from its amount in both vegetated and non-vegetated areas. In which, its size was 48037.79 ha, the total amount of carbon emission was 164187.83 $\mathrm{C}$ tons or 0.60 Mton $\mathrm{CO} 2$-eq.

\section{CONCLUSION}

There is changing landcover pattern taking place in the concession area, a contracted area in Kutai Kertanegara forest used for coal mines. Size of areas that consist of wet shrubs, crop estate, dry-land farming, dry-land farming and shrubs, open area, mining, residential areas and water is increasing while those that consist of secondary dry-land forest, forest plantation, shrubs, and rice fields are decreasing. The findings showed 12,663.38 hectares of the forest had been shifted into different lancover change. The amount of carbon

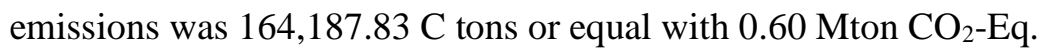

Satellite imaging with very high resolution and field survey/observation are two data collection methods to get more accurate and trustworthy information.

\section{ACKNOWLEDGEMENT}

This study is funding by student work scholarship programme of Ministry Environment and Forestry of Republic of Indonesia. 


\section{REFERENCES}

Abood, Sinan et al. 2015. Relative Contributions of Log-ging, Fiber, Oil Palm, and Mining Industries to Forest Loss in Indonesia. Conservation Letters. 8(1): 58 -67. doi: 10.1111/conl.12103.

Adhikari A and White JD. 2016. Climate Change Impacts on Regenerating Shrubland Productivity. Ecological Modelling. 337: 211-220. https://doi.org/10.1016/j.ecolmodel.2016.07.003. [downloaded April $4^{\text {th }}$, 2018].

Ahlering M, Fargione J and Parton W. 2016. Potential Carbon Dioxide Emission Reductions from Avoided Grassland Conversion in The Northern Great Plains. Ecosphere. 7(12): e01625. doi: 10.1002/ecs2.1625.

Amichev BY, Burger JA, and Rodrigue JA. 2008. Carbon Sequestration by Forests and Soils on Mined Land in The Midwestern and Appalachian Coalfields of The US. Forest Ecology and Management. 256 (11): 1949-1959. https://doi.org/10.1016/j.foreco.2008.07.020. [downloaded April $4^{\text {th }}, 2018$ ].

Directorate General of Forestry Planning. 2015. Regulation of Director General of Forestry Planning No. P.1 / VII-IPSDH / 2015 on Guidelines for Monitoring Forest Resources. Jakarta

Agus et al. 2013. Technical Guidelines for Calculating Baseline Emissions and Land-Based Greenhouse Gas Absorption: Book I Scientific Basis. Jakarta: National Development Planning Agency, Republic of Indonesia.

Ferreira, Nilson C. et al. 2011. Assessing deforestation related carbon emission in the Brazillian Savana based on moderate resolution imager. IEEE Geosciences and Remote Sensing Symposium 2011. [Internet]. [Unknown time and place of meeting]. [Downloaded August 16 ${ }^{\text {th }}, 2016$ ].

Goetz, Scott and Dubayah, Ralph. 2011. Advances in remote sensing technology and implications for measuring and monitoring forest carbon stocks and change. Carbon Management. 2(3): 231-244. doi: 10.4155/cmt.11.18.

Guan C, Zhang B, Li J, Zhao J. 2017. Temporal and Spatial Changes of Land Use and Land-scape in A Coal Mining Area in Xilingol Grassland. IOP Conference Series: Earth and Environmental Science. 52(1): p. 012052. doi:10.1088/1755-1315/52/1/012052.

Gunawan, Rahmi Anna Fahria and Leksono, Amin Setyo and Afandhi, Aminudin. 2017. Land use change and carbon stock dynamics in Tuban, East Java, Indonesia. Ecology, Environment and Conservation Paper. 23 (1): 71-76. [Internet]. www.envirobiotechjournal.com. [downloaded February 15 ${ }^{\text {th }}, 2018$ ]

Hairiyah, Kurniatun and Ekadinata, Andree and Sari and Rika Ratna, and Rahayu, Subekti. 2011. A Practical Guide to Measuring Carbon Reserves from Land to Landform Level. Bogor: World Agroforestry Center, ICRAF SEA Regional Office University of Brawijaya (UB) Malang, Indonesia.

Handoyo and Cicilia S. 2014. Indonesia's exports of forest products continue to rise. https://industri.kontan.co.id/news/ekspor-produk-hasil-hutan-indonesia-terus-naik. [Downloaded April 5 $\left.5^{\text {th }}, 2018\right]$

Huang Y, Tian F, Wang Y, Wang M and Hu Z. 2015. Effect of coal mining on vegetation disturbance and associated carbon loss. Environment Earth Science. 73: 23-29. https://doi.org/10.1007/s12665-0143584-z. [downloaded April 5 $5^{\text {th }}$, 2018].

Lutfi M, Antono, Harry T. 2011. Biomass estimation on reclamation area using Alos Palsar image data: Case Study of coal mining work area in East Kalimantan. Minerals and Coal. 9(3): 50 - 58.

Margono, Belinda Arunarwati and Turubanova, Svetlana and Zhuravleva, Ilona and Potapov, Peter and Tyukaniva, Alexandra, and Baccini, Alessandro and Hansen, Mat-thew C. 2012. Mapping and monitoring deforestation and forest degradation in Sumatra (Indonesia) Using Landsat time series data sets from 1990 to 2010. Environmental Research Letters. 7: 1 - 16. doi:10.1088/17489326/7/3/034010. 
Munawar, Sana et al. 2015. Reducing emissions from deforestation and forest degradation implementation in Northern Pakistan. International Biodeterioration and Biodegradation Journal. 102: 316 - 323. http://dx.doi.org/10.1016/j.ibiod.2015.02.027.

National Council of Energy. 2014. Outlook Energy of Indonesia 2014. Jakarta.

National Standardization Agency. 2010. Indonesia National Standard No. 7645:2010, Landcover Classificaton. Jakarta.

National Standardization Agency. 2014. Indonesia National Standard No. 8033:2014, Method for Calculating Forest Cover Change Based on Visual Optical Remote Sensing Imagery. Jakarta.

Olofsson, Pontus et al. 2010. Implications of land use change on the national terrestrial carbon budget of Georgia. Carbon Balance and Management. 5(4). http://www.cbmjournal.com/content/5/1/4. [Downloaded September 11 $\left.{ }^{\text {th }}, 2016\right]$.

Samanta, Prasenjit. 2015. Impact Assessment and changes analysis of land use/ land cover due to open cast coal mining activity: A case study of Raniganj coal field area. International Journal of IT, Engineering and Applied Sciences Research (IJIEASR). 4(5): 17 - 26.

Sihombing BH. 2013. Analisis perubahan tutupan lahan areal konsessi tambang PT Kaltim Prima Coal. Agrifor. 11(2): 83-89.

Sonter, Laura Jane et al. 2013. Mining, deforestation and conservation opportunities: A case study of the Quadrilátero Ferrífero land use change dynamics. 16th Brazil Remote Sensing Symposium. 13 - 18 April 2013.

Sonya, Dewi, S, Suyanto S, and van Noordwijk, M. 2012. Institutionalizing Emissions Reduction as a Sustainable Development Planning Part at the National and Sub-National Levels in Indonesia. Brief No 31. Bogor, Indonesia. World Agroforestry Centre - ICRAF, SEA Regional Office. 6p.

Suhanto E. 2010. Overlapping Analysis Among Mining Areas and Protected Forest Area and Conservation: A Case Study of Mineral Potential of Copper-Copper and Coal in Sumatra Island [Master Theses Mining Engineering]. http://digilib.itb.ac.id.

Yadav SK and Borana SL. 2017. Monitoring and temporal study of mining area of Jodhpur City using remote sensing and GIS. International Research Journal of Engineering and Technology (IRJET). 4(10): 1732 $-1736$. 